\title{
Preparedness for Mass Gathering During Hajj and Umrah
}

\author{
Iman Ridda, Sarab Mansoor, Revlon Briggs, Jemal Gishe, and \\ Doaha Aatmn
}

\section{Contents}

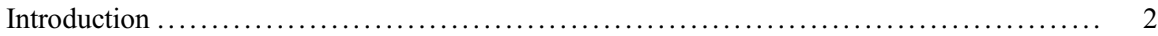

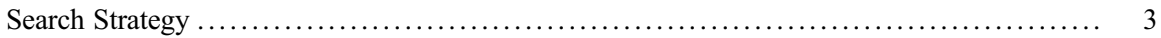

Mass Gatherings and the Role of Public Health .................................. 3

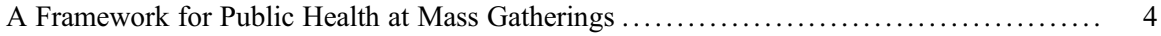

Public Health Surveillance ................................................. 5

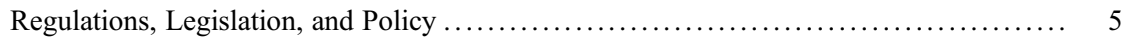

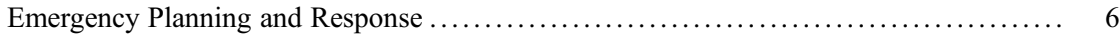

Environmental Health ................................................... 6

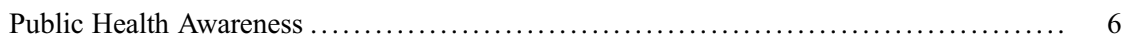

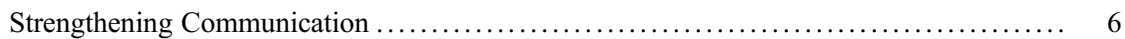

Internal Organizational and Capability Building .............................. 6

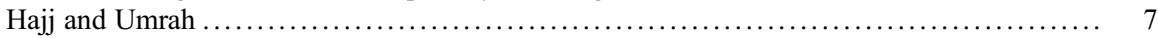

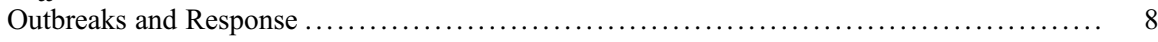

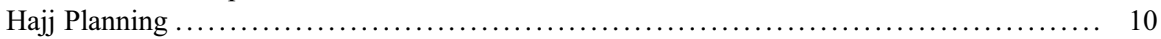

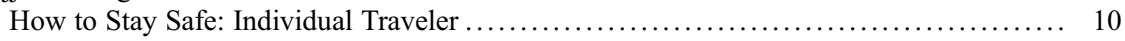

How to Stay Safe: Role of Health Authorities .............................. 16

Government Preparedness ................................................ 16

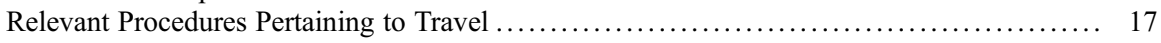

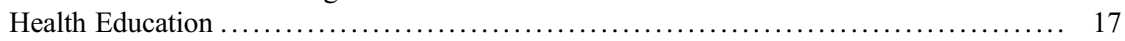

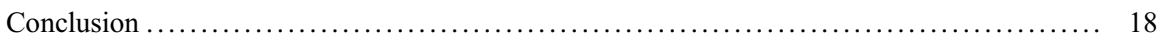

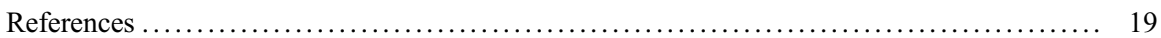

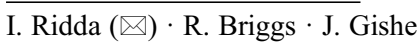

Department of Public Health, Health Administration, and Health Sciences,

Tennessee State University, Nashville, TN, USA

e-mail: imrd512@hotmail.com; rbriggs@tnstate.edu; jgishe@tnstate.edu

S. Mansoor

The University of Sydney School of Pharmacy, NSW, Australia

e-mail: sarabmalikmansoor@hotmail.com

D. Aatmn

California University of Science and Medicine,

San Bernardino, CA, USA

e-mail: AtamnD@calmedu.org 


\section{Abstract}

The role of public health preparedness at mass gatherings (MGs) and a framework to ensure a safe and healthy mass gathering are provided in this chapter. The unique aspects of Hajj and Umrah events, including their massive size and the interplay of environmental conditions with the international nature of attendees, require proper and thorough public health preparation.

The key aspects of a framework designed to promote public health at mass gatherings are also outlined in this chapter. The key aspects include risk assessment, public health surveillance; regulations, legislation and policy; emergency planning and response; environmental health; public health awareness; strengthening communication; and internal organizational and capacity building. Our search evaluates literatures pertaining to the frameworks of public health concerns at mass gatherings and analyzes the preparedness and effectiveness of such regulations and projections in current models of disaster preparedness and public health promotion. Such a model is crucial for setting the stage for decision-making and ensuring the safety of attendees; it should be implemented before the commencement of the event.

Further, the health risks associated with attending a mass gathering such as Hajj/Umrah are discussed. Clinicians and attendees have specific roles to play in ensuring good public health during these pilgrimages. Clinicians have a role in ensuring attendees are well equipped with the knowledge and resources to stay healthy during Hajj/Umrah, which helps to protect the public from infectious disease transmission. Attendees have a role in ensuring personal health and maintaining hygiene standards. Infectious diseases of concern at such mass gatherings include Middle East respiratory syndrome-coronavirus (MERS$\mathrm{CoV}$ ), meningococcal disease, diarrheal disease and seasonal influenza. Other diseases of concern include the potential for pilgrims to contract Zika due to local populations of Zika vectors.

Specific vaccine requirements and knowledge regarding health warnings are crucial to Hajj attendees when traveling to the Kingdom of Saudi Arabia (KSA). In addition, pilgrims are encouraged to seek accurate information related to travel and visas and requirements of Hajj-specific travel visas.

\section{Keywords}

Hajj $\cdot$ Public health $\cdot$ Mass gathering $\cdot$ Preparedness $\cdot$ Vaccine

\section{Introduction}

The World Health Organization (WHO) defines mass gatherings as a planned or spontaneous event where at least 1000 individuals gather at a specific location for a specific purpose and defined period of time. The size of such gatherings increases the risk of certain public health issues and requires special attention to mitigate these risks (WHO 2005). Without proper planning and foresight, such events can 
put a strain on the health response resources of the community or country hosting the event, as well as a strain on global health responses, since these attendees are a part of a global population with diverse countries of return and origin (Leangapichart et al. 2017; Khan et al. 2017; Rahimian and Hosseini 2017; Cobbin et al. 2017; WHO 2015). Events such as the Olympic Games, political rallies, and religious assemblies like Hajj are examples of mass gatherings that attract a large number of people (WHO 2015). Mass gatherings can also include displaced populations due to natural disasters, conflicts, and wars.

This chapter examines available literature on the burden of mass gatherings during Hajj as a case study and identifies health-related requirements and recommendations for obtaining an entry visa to attend Hajj and Umrah. The information provided in this document can be a source of information that will add to general knowledge and is intended to be of assistance to governments at all levels and communities involved in overseeing leading public health preparedness efforts. Identifying public health risks associated with Hajj and Umrah, as well as the gaps in current literatures and research, will mitigate shortcomings in procedures and structures associated with disaster preparedness and the risks and hazards posed by such mass gatherings.

\section{Search Strategy}

Key databases were searched from late mid-September 2016 to early- March 2018 to identify items on Hajj, mass gathering, public health preparedness and/or outbreak and responses in Hajj and in Umrah pilgrims. Our search focused only on planned mass gatherings. Manuscripts were excluded if the focus of the mass gathering event was outside Hajj and Umrah. Databases searched include the Centers for Disease Control and Prevention (CDC), OVID Medline, OVID Em-base, and Web of Science databases consisting of the Science Citation Index, Social Sciences Citation Index, Conference Proceedings Citation Index-Science, and Conference Proceedings Citation Index-Social Science and Humanities.

\section{Mass Gatherings and the Role of Public Health}

Public health plays an important strategic and technical role in keeping the public safe and healthy during mass gatherings. Epidemiologic surveillance, environmental management, emergency care, disease prevention, access to information, and strong leadership are critical elements at mass gatherings (Tsouros and Efstathiou 2007; Kazi et al. 2017). The role of public health officials at mass gatherings is to assure conditions through which all attendees remain safe and healthy for the duration of such gatherings.

While some gatherings are brief and may last for a day or less, most religious gatherings for Muslims are usually longer. The focus of this chapter is to examine the role of public health officials during the Hajj and Umrah events, which are annual 


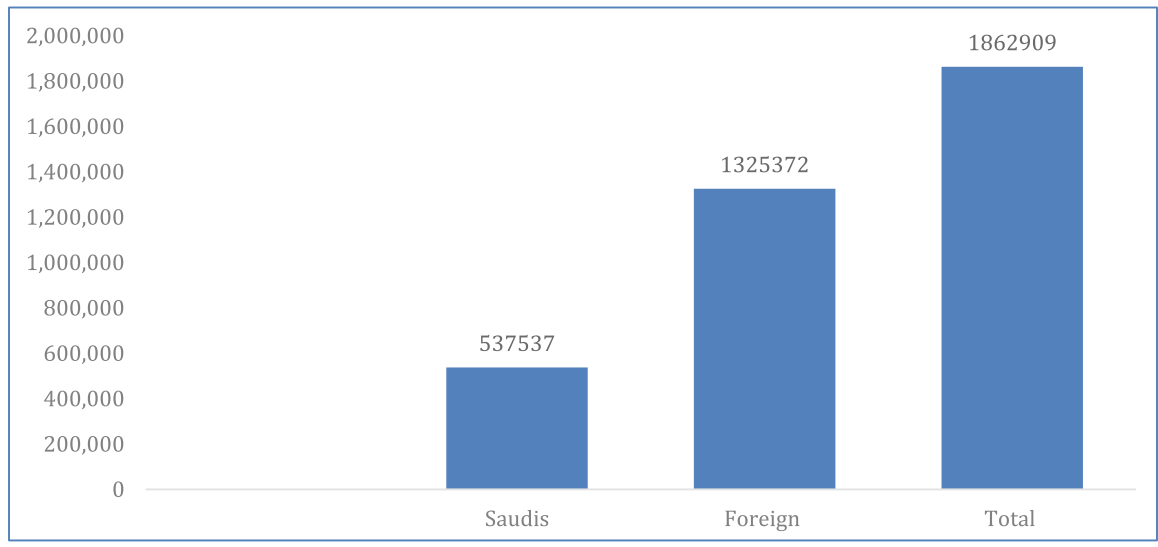

Fig. 1 Total pilgrims in 2016 by origin. (Hajj Statistics 2016. General Authority for Statistics, Kingdom of Saudi Arabia. Accessed at https://www.stats.gov.sa/sites/default/files/hajj_1437_en. pdf)

gatherings of Muslims: Hajj which occurs once a year and Umrah, which can be performed at any time. Attendance during these events is massive as more than two million Muslims from 183 countries perform Hajj each year (Fig. 1).

With these massive crowds, it is critical that health officials remain vigilant in exploring all avenues to preserve health through reduction of risk for injury, institute robust surveillance to avert the spread of disease among attendees, and treat attendees who become ill. Mass gatherings have significant public health implications that extend beyond acute health events and require rapid detection and effective management (Tsouros and Efstathiou 2007). Mass gatherings can increase health security risks, raise social anxiety, political urgency, and cause economic disruption if steps are not taken to organize and respond effectively.

To assure safety during a mass gathering, preparations and necessary precautions must be taken not only by attendees but also by sponsors and leaders in host countries. A general public health framework for keeping crowds safe, and historic examples of Muslim gatherings with specific recommendations to Hajj pilgrims are provided in this chapter.

\section{A Framework for Public Health at Mass Gatherings}

Historically, peer-reviewed literature has concentrated on Hajj and Umrah as examples of mass gatherings that require public health-related responses (Tsouros and Efstathiou 2007). The size of the gathering, diversity of population, the climate, health facilities around the Hajj sites, and emergency management systems all make this gathering a special and unique opportunity for the public health community to invest and play an essential role. Proper preparation for mass gatherings requires a substantial investment and capacity built between the 
local officials, the community, and the attendees (WHO 2015). Preparation should start early and include detailed policies and procedures that involve health partners, public health providers, and emergency services.

A framework that connects the psychosocial, biomedical, and environmental domains of public health preparation and response for mass gatherings is a useful tool to verify that proper steps have been taken to ensure a safe and healthy gathering (Arbon 2004). The framework described will help set the stage for a broader view of decision-making while planning the safety of attendees. In addition to higher level organizational and government requirements with a public health lens, the roles and responsibilities are discussed for attendees to contribute to a safe and well-executed mass gathering. The framework to reduce risks in mass gatherings includes the following:

\section{Public Health Surveillance}

A robust public health surveillance system on-site for attendees is key to keeping crowds safe at mass gatherings, which allows faster notification and response to potential hazards. A surveillance system is important because strengthened systems will improve resiliency and allow for greater event capacity. This system requires integration of data from multiple sources (such as surveillance data, laboratory results, the intelligence community, and the media) into succinct and accessible reports for decision-makers.

To achieve better public health surveillance, and thus improve global security, implementers can build upon existing response services to identify gaps and efficiently use the technology that is available. Use of technologies in an innovative way, such as the use of Short Message Service (SMS) to distribute health messages to attendees, is one example of this strategy (WHO 2015).

\section{Regulations, Legislation, and Policy}

The development of a public health surveillance system may seem like a large, daunting task. However, this investment can effectively reduce overall costs and keep populations safe over time. To achieve this, decision-makers must revise policy, regulation, and legislation to create plans that are cost-effective and appropriate to improve health outcomes at mass gatherings. Support of the government and cooperation between all stakeholders, while learning from past incidents, is key to public health preparedness for such mass gatherings (Aleeban and Mackey 2016; WHO 2015). 


\section{Emergency Planning and Response}

The next step requires emergency planning and response arrangements that are both coordinated and efficient. Key players must understand their roles and responsibilities. A robust emergency response system is one that is tested, evaluated, adaptable, and adjustable (Tsouros and Efstathiou 2007; WHO 2015).

\section{Environmental Health}

Attention to the environment where the mass gathering takes place is a critical component for the health of gatherers. Air quality maintenance, frequent decontamination of the event site, improved hygiene and waste disposal facilities, enforcement of food safety practices, safe drinking water, and an infrastructure to reduce foodborne diseases are all essential elements that impact the wellbeing of the public (Tsouros and Efstathiou 2007; WHO 2015).

\section{Public Health Awareness}

The healthier and more prepared attendees are during the mass gathering, the more likely the event will be successful. To ensure the success of a gathering, efforts should be made to inform the public of imposing risks and actions they can take to prepare before they attend. Examples of this include vaccination campaigns, information about environmental conditions, as well as the level of fitness or stamina needed to safely participate. Open access to health and safety information can enhance relationships and trust between governments, health officials, and the people, thereby, improving the credibility of health organizations as an authoritative voice for public health issues (Alqahtani et al. 2015; Rahman et al. 2016; WHO 2015).

\section{Strengthening Communication}

Improved communications across all stakeholders, including the host country's government, agencies, the private sector, the public, and all the organizers increase the understanding of roles and responsibilities toward reducing the risk associated with mass gatherings and providing the best prevention (WHO 2015).

\section{Internal Organizational and Capability Building}

To ensure sustainable systems that can handle repeat mass gatherings and improve the quality of future events, internal organizations must build capacity with all stakeholders by working to improve working arrangements, ensure understanding 
of roles and responsibilities, and improve the working arrangements for all national and international partners (WHO 2015).

\section{Hajj and Umrah}

The Hajj and Umrah religious mass gatherings hosted by the Kingdom of Saudi Arabia (KSA) have historically challenged the existing public health systems and has provided important case studies for mass gathering preparedness. The largest annual pilgrimage to Mecca KSA, is the Hajj, a geographically and ethnically diverse mass gathering.

Performing Umrah is not obligatory and can be a smaller scale pilgrimage than Hajj, but not necessarily. Unlike Hajj, Umrah does not have a fixed time or date to be performed, but there are times when the gatherings rival those of the Hajj pilgrimage, such as those pilgrimages which occur during the last 10 days of Ramadan. Hajj is the fifth pillar of Islam and is a mandatory religious duty for financially and physically able-bodied Muslims. In it, pilgrims follow the footsteps of Prophet Ibrahim (one of the Prophets of Islam) and his family. The Hajj Pilgrimage occurs from the 8th to the 12th of Dhul al-Hijah, the last (12th) month of the Islamic (lunar) calendar. This holy journey requires pilgrims to perform 10 rituals before and during Hajj.

Upon arrival at the entrance of the Holy City, pilgrims from more than 185 countries enter the state of ihram or state of purity where they remain throughout the Hajj. Males in the state of ihram wear two white seamless sheets wrapped around their bodies and sandals. This practice signifies the state of holiness and contributes to the sense of equality through the removal of materialistic signs of wealth, class, and culture. For women, during the state of ihram, normal white clothing is worn with only their faces and hands uncovered. In the state of ihram, pilgrims are prohibited from cutting their hair and nails, engaging in sexual activity, and acts of violent behavior (Armstrong 2002).

Eid al-Adha is the 10th day of Hajj, a major holiday observed by all Muslims. For Hajj participants, the day is spent in Mina. Pilgrims sacrifice an animal in commemoration of Abraham's sacrificing his son Ismail, along with throwing seven small stones at each of the three pillars. The pillars are symbolic of the devil, and pilgrims throw stones at the pillars for three consecutive days. The pilgrims then return to Mecca where they perform Tawaf for the second time. Pilgrims shave or trim their hair marking the completion and state of ihram (Armstrong 2002). This religious event lasts for 5 days and attracts over two million Muslims from around the world.

The approximately three million pilgrims are hosted in a relatively small area, many of whom are housed in the tent city of Mina. In the first place, this global mass gathering poses a risk for transmission of infectious diseases on a mass scale. The tent city also poses several serious public health concerns, for in addition to the language barriers and sheer mass of the gathering, the gatherers are so focused on their purpose that bodily or physical concerns may be put off or disregarded for the 
duration of the pilgrimage. The diversity of the group creates a barrier for the dissemination of knowledge and precautionary measures, thus an informational dearth is automatically a cause for concern. In addition to that, however, there is the practical issue of national origin. The transmission of diseases not picked up by preliminary physical examinations will be carried from person to person and, ultimately, from country to country. The way these pathogens and illnesses behave in their new environments can be unpredictable, and the physical space of the gathering becomes a concern for susceptible members of the groups, such as the elderly and those without adequate prior protection against infection and disease.

In addition to the risk of imported pathogens heightening the risk of infectious diseases spreading worldwide, the size of the gathering is at risk for various structural dangers. Vehicular accidents, structural issues, and stampedes are examples of risks posed by size and mass and close quarters. Stampedes, which can be attributed to inaccurate transmissions of information and language barriers as well as sheer size, are another risk posed by a mass gathering (Alaska et al. 2016). Due to the size and scope of this event, prior incidents of infectious disease transmission, injuries due to stampedes, and motor vehicle accidents, there is an important opportunity for collaboration between the host country and pilgrims to minimize the risk of illness and promote the best prevention and health promotion guidelines.

In regard to the public health issues relating to the Hajj and the Umrah and the nature of mass gatherings, this chapter will address communicable issues such as the transmission of infectious diseases, the preventative measures taken such as risk assessments and disaster preparedness, and noninfectious or noncommunicable issues such as structural failures and physical injury.

\section{Outbreaks and Response}

Like all mass gatherings, there is an increased risk for pilgrims to contract and spread certain infectious diseases due to the environmental conditions at the Hajj. The communicable risks associated with mass gatherings are less relevant to their size and the population, and more a result of global travel and behavioral practices at mass gathering events.

Several factors contribute to the prevalence of these transmittable diseases, including direct contact with infected people, climatic conditions, overcrowding, cigarette smoking, and exposure to allergens, which are the main contributing factors present in the Hajj environment. Under these circumstances, it is not surprising to find that a significant number of pilgrims have an attack of one or more infectious disease during or immediately after the Hajj performance (Shafi et al. 2016). Such a high incidence of illness causes a significant burden to Hajj pilgrims. In addition, it is also important to consider that pilgrims can be a source of infectious disease transmission on their return home, making the infectious transmission a global health risk (Gautret et al. 2016; Shafi et al. 2016; Yezli et al. 2017; Abd El Ghany et al. 2017; Shirah et al. 2017). 
Historically, infectious disease outbreaks were common during Hajj in the nineteenth and twentieth centuries. For example, meningococcal diseases had large outbreaks in the late 1980s and early 2000s (Lingappa et al. 2003). The outbreaks prompted Saudi authorities to implement prevention efforts and policies, investing in strict vaccination and chemoprophylaxis policies (Yezli et al. 2016). Although improvements have been realized in some cases, proactive surveillance of the transmission of potential epidemic threats at Hajj are critical and must be sustained to continue to preserve global health at mass gatherings (Shafi et al. 2016).

The Middle East respiratory syndrome coronavirus (MERS-CoV), meningococcal disease, diarrheal disease, and respiratory illnesses such as seasonal influenza and pandemic $\mathrm{H} 1 \mathrm{~N} 1$ are the most common outbreaks that travelers and organizers need to combat and protect against (US Centers for Disease Control and Prevention (CDC) 2015; United States Department of State [Overseas Security Advisory Council (OSAC)] 2015; Finger et al. 2016; Alqahtani et al. 2016a); Al-Tawfiq et al. 2016, and health officials are worried that pilgrims may acquire the coronavirus that causes Middle East respiratory syndrome (MERS) when they travel to Mecca and unknowingly take it back to their home country, thus, spreading it globally (Coghlan 2015).

A major historical concern at Hajj was an isolated case of MERS-CoV identified in a 68-year-old patient, dying of pneumonia and multiorgan failure in Jeddah in June 2012 (Zaki et al. 2012). While the concern of the virus becoming an epidemic is low, there has been an increase in cases in the region (Zumla et al. 2016). Serological studies show that MERS-CoV was a common infection in dromedary camels approximately 20 years ago, and there is accumulating evidence that the sporadic human outbreaks are seeded by zoonotic infection from camels.

The past three Hajj pilgrimages were completed without an increase in travelrelated MERS-CoV cases. However, KSA authorities prepared for the potential emergence of MERS-CoV with existing healthcare systems in place and resources to address such cases. Health officials of other healthcare institutions and countries have been vigilant in their efforts advising pilgrims to take precautions to minimize health risks. Pilgrims with chronic medical conditions such as diabetes or chronic heart failure, or individuals, who are immune-compromised, are at an increased risk of MERS-CoV disease and should seek medical consultation before performing Hajj. The risk of MERS-CoV is more apparent after exposure to camels or camel products. Therefore, pilgrims are advised to avoid visiting areas where camels congregate, and avoid consuming camel products or foods contaminated with camel secretions. Pilgrims exposed to the virus are advised to seek medical attention promptly and should inform their clinician of their travel to KSA (Zumla et al. 2016). Today, there are steps that authorities, clinicians, and pilgrims can take to reduce the risks of these outbreaks. 


\section{Hajj Planning}

\section{How to Stay Safe: Individual Traveler}

\section{Pre-travel Preparation}

While vaccination is an important control measure for the prevention of disease outbreaks during Hajj, health education is also critical in preventing disease (Ministry of Health Saudi Arabia 2017). Pilgrims should seek advice about the health risks before traveling to the KSA for Hajj/Umrah. Health advice can be provided by Hajj travel agents, tour guides, and healthcare professionals who are involved in planning interventions to educate pilgrims about possible diseases and how to avoid them (Shafi et al. 2016; Alqahtani et al. 2015, 2016a).

Pilgrims also should be up to date on routine vaccinations, and see their healthcare professional before traveling to get advice on vaccinations, food and water intake, best hygiene practices, and injury prevention (Ministry of Health Saudi Arabia 2017). In addition, healthcare professionals should ensure that pilgrims are physically fit before traveling, discuss the suitability of travel with pilgrims who have pre-existing medical conditions, and ensure that pilgrims have a sufficient supply of their medications and carry a copy of necessary prescriptions (United States Department of State 2015).

Healthcare professionals should emphasize the importance of pilgrims to adhere to the Ministry of Health (MOH) of KSA recommendations (Table 1) and comply with health guidelines to prevent the spread of diseases during Hajj/Umrah season:

Pilgrims also have an important role in maintaining public health during Hajj/ Umrah. Pilgrims must have their vaccination certificate ready for inspection by Saudi authorities at the port of entry (Bowron and Salahudin 2015). In addition to the standard vaccination requirements, there are additional vaccines necessary for entry to Saudi Arabia particularly during Hajj and Umrah seasons. Vaccinations for travelers are listed in Table 2.

Table 1 Common health recommendations to Hajj pilgrims to curb the spread of disease during Hajj/Umrah

\begin{tabular}{l|l}
\hline $\begin{array}{l}\text { Personal } \\
\text { hygiene }\end{array}$ & $\begin{array}{l}\text { Wash hands with soap and water or disinfectant, especially after coughing or } \\
\text { sneezing, after using the toilet, before handling and consuming food, and after } \\
\text { touching objects and animals } \\
\text { Use disposable tissues when coughing or sneezing and dispose of them in the } \\
\text { dustbin } \\
\text { Avoid touching the eyes, nose, and mouth with hands }\end{array}$ \\
\hline In public & $\begin{array}{l}\text { Avoid direct contact with people who appear to be ill (i.e., who are coughing, } \\
\text { sneezing, vomiting, or have diarrhea) } \\
\text { Do not share personal belongings } \\
\text { Wear a mask when in crowded places }\end{array}$ \\
\hline $\begin{array}{l}\text { Around } \\
\text { animals }\end{array}$ & $\begin{array}{l}\text { Avoid contact with animals } \\
\text { Avoid drinking raw camel milk or eating meat that has been cooked improperly }\end{array}$ \\
\hline
\end{tabular}

Ministry of Health Saudi Arabia (2017): Health Guidelines during Hajj 
Table 2 Required and recommended vaccinations for Hajj attendees

\begin{tabular}{|c|c|c|c|}
\hline $\begin{array}{l}\text { Recommended } \\
\text { vaccines }\end{array}$ & Description & $\begin{array}{l}\text { Required } \\
\text { vaccines }\end{array}$ & Description \\
\hline Hepatitis A & $\begin{array}{l}\text { Hajj conditions (low food } \\
\text { hygiene standards, sharing } \\
\text { common toilets), pilgrim } \\
\text { behaviors and ritual } \\
\text { activities (share/reuse of } \\
\text { razor blades for mandatory } \\
\text { head shaving for men, } \\
\text { improper disposal of razor } \\
\text { blades, cuts when } \\
\text { sacrificing animals) lead to } \\
\text { increase food-borne } \\
\text { (hepatitis A virus (HAV). } \\
\text { The WHO (2016a) } \\
\text { suggests inactivated } \\
\text { hepatitis A vaccines have a } \\
\text { long-lasting protective } \\
\text { efficacy of } 90-95 \% \text { in both } \\
\text { children and adults. Two- } \\
\text { dose vaccination schedule } \\
\text { is preferred, but one dose } \\
\text { also induces similar } \\
\text { responses (Abd El Ghany et } \\
\text { al. 2016); Rafiq et al. 2009) }\end{array}$ & $\begin{array}{l}\text { Meningococcal } \\
\text { meningitis }\end{array}$ & $\begin{array}{l}\text { Visitors of the Umrah/Hajj } \\
\text { are required to receive the } \\
\text { tetravalent (ACYW135) } \\
\text { vaccine to protect against } \\
\text { meningitis. It should be } \\
\text { received no more than } \\
3 \text { years or less than } 10 \text { days } \\
\text { prior to arrival. KSA } \\
\text { requires proof of all } \\
\text { vaccination upon arrival } \\
\text { for Hajj pilgrims. Hajj has } \\
\text { been associated with } \\
\text { outbreaks of } \\
\text { meningococcal disease in } \\
\text { returning pilgrims and } \\
\text { people in close contact } \\
\text { with them, making } \\
\text { vaccination crucial for all } \\
\text { attendees. }\end{array}$ \\
\hline $\begin{array}{l}\text { Seasonal } \\
\text { Influenza }\end{array}$ & $\begin{array}{l}\text { The Ministry of Health of } \\
\text { Saudi Arabia recommends } \\
\text { receiving the most recent } \\
\text { influenza vaccine before } \\
\text { arrival to KSA. Influenza } \\
\text { vaccine is highly } \\
\text { recommended for pregnant } \\
\text { women, children > } \\
5 \text { years, elderly, and } \\
\text { individuals who are } \\
\text { immune-compromised and } \\
\text { have pre-existing chronic } \\
\text { conditions. The } \\
\text { vaccination is further } \\
\text { recommended for internal } \\
\text { pilgrims in Saudi Arabia } \\
\text { who have the same pre- } \\
\text { existing health conditions } \\
\text { aforementioned as well as } \\
\text { healthcare workers within } \\
\text { the vicinity of Hajj and } \\
\text { Umrah (Algarni et al. } \\
\text { 2016). }\end{array}$ & \multirow[t]{2}{*}{ Poliomyelitis } & \multirow[t]{2}{*}{$\begin{array}{l}\text { Documentation is required } \\
\text { for oral polio vaccine } \\
\text { (OPV) or inactivated } \\
\text { poliovirus vaccine (IPV) } \\
\text { regardless of age and } \\
\text { vaccination status } \\
\text { (Ministry of Health Saudi } \\
\text { Arabia 2017). This vaccine } \\
\text { is required within } 4 \text { weeks } \\
\text { to a year prior to departure } \\
\text { for Saudi Arabia and entry } \\
\text { visa for pilgrims arriving } \\
\text { from the following } \\
\text { countries, territories or } \\
\text { areas: } \\
\text { 1. Populations with } \\
\text { endemic virus } \\
\text { transmission: Afghanistan, } \\
\text { Nigeria, and Pakistan; } \\
\text { 2. Populations with } \\
\text { circulating vaccine-derived } \\
\text { poliovirus within the past } \\
\text { 12 months: Cameroon and } \\
\text { Somalia; } \\
\text { 3. Populations that remain } \\
\text { vulnerable to polio: }\end{array}$} \\
\hline Typhoid & $\begin{array}{l}\text { The Typhoid vaccine is } \\
\text { recommended for almost } \\
\text { all international travelers. }\end{array}$ & & \\
\hline
\end{tabular}


Table 2 (continued)

\begin{tabular}{|c|c|c|c|}
\hline $\begin{array}{l}\text { Recommended } \\
\text { vaccines }\end{array}$ & Description & $\begin{array}{l}\text { Required } \\
\text { vaccines }\end{array}$ & Description \\
\hline & $\begin{array}{l}\text { Hajj pilgrims can get } \\
\text { Typhoid through } \\
\text { contaminated food or water } \\
\text { in Saudi Arabia. The CDC } \\
\text { (2017) recommends this } \\
\text { vaccine for most travelers, } \\
\text { especially if they are } \\
\text { staying with friends or } \\
\text { relatives and/or visiting } \\
\text { smaller cities or rural areas. }\end{array}$ & & \multirow{4}{*}{$\begin{array}{l}\text { Equatorial Guinea, } \\
\text { Ethiopia, Iraq, Palestine } \\
\text { (the West Bank and Gaza } \\
\text { Strip), Syrian Arab } \\
\text { Republic and Yemen. } \\
\text { Travelers from these } \\
\text { countries will receive an } \\
\text { additional dose of OPV at } \\
\text { border checkpoints upon } \\
\text { arrival in Saudi Arabia. } \\
\text { It is encouraged for } \\
\text { travelers from polio-free } \\
\text { countries to be vaccinated } \\
\text { as well as they may be at } \\
\text { particular risk of } \\
\text { importation (Algarni et al. } \\
\text { 2016). }\end{array}$} \\
\hline $\begin{array}{l}\text { Varice-lla } \\
\text { (Chicken Pox) }\end{array}$ & $\begin{array}{l}\text { CDC (2017) recommends } \\
\text { that all travelers to Saudi } \\
\text { Arabia are up to date on } \\
\text { their Varicella vaccines. }\end{array}$ & & \\
\hline Diphtheria & $\begin{array}{l}\text { The Centers for Disease } \\
\text { Control and Prevention } \\
\text { (2017) recommends that all } \\
\text { travelers to Saudi Arabia } \\
\text { are up to date on their } \\
\text { Diphtheria vaccines. }\end{array}$ & & \\
\hline Tetanus & $\begin{array}{l}\text { The CDC (2017) } \\
\text { recommends that all } \\
\text { travelers to Saudi Arabia } \\
\text { are up-to- date on their } \\
\text { Tetanus vaccines. If } \\
\text { pilgrims have not received } \\
\text { a Tetanus booster within } \\
\text { the past } 10 \text { years, it is } \\
\text { recommended that this is } \\
\text { received before travel to } \\
\text { Saudi Arabia. }\end{array}$ & & \\
\hline Malaria & $\begin{array}{l}\text { Pilgrims may need to take } \\
\text { prescription medication } \\
\text { before, during, and after } \\
\text { their trip to prevent } \\
\text { malaria, depending on their } \\
\text { travel plans. Hajj pilgrims } \\
\text { should consult their } \\
\text { medical professional to } \\
\text { discuss where they are } \\
\text { traveling, when they are } \\
\text { traveling, and if they are } \\
\text { spending a lot of time } \\
\text { outdoors or sleeping } \\
\text { outside. }\end{array}$ & Yellow Fever & $\begin{array}{l}\text { All travelers from regions } \\
\text { with yellow fever } \\
\text { prevalence are required to } \\
\text { have yellow fever } \\
\text { vaccination certificates } \\
\text { (Ministry of Health Saudi } \\
\text { Arabia 2017). WHO } \\
\text { regularly updates the list of } \\
\text { countries that are at risk for } \\
\text { yellow fever. Travelers } \\
\text { should check this list or } \\
\text { discuss with their health } \\
\text { providers prior to traveling } \\
\text { (WHO 2016b). As at 2017, } \\
\text { affected countries include: }\end{array}$ \\
\hline
\end{tabular}


Table 2 (continued)

\begin{tabular}{|c|c|c|c|}
\hline $\begin{array}{l}\text { Recommended } \\
\text { vaccines }\end{array}$ & Description & $\begin{array}{l}\text { Required } \\
\text { vaccines }\end{array}$ & Description \\
\hline Pneumonia & $\begin{array}{l}\text { It is recommended that all } \\
\text { children under the age of } \\
\text { five and all adults over the } \\
\text { age of } 50 \text { who are traveling } \\
\text { to Saudi Arabia for Hajj } \\
\text { receive the STS } \\
\text { pneumococcal vaccination } \\
\text { before traveling (Alharbi et } \\
\text { al. 2016). }\end{array}$ & & \multirow{2}{*}{$\begin{array}{l}\text { Angola, Argentina, Benin, } \\
\text { Bolivia, Brazil, Burkina } \\
\text { Faso, Burundi, Cameroon, } \\
\text { Central African Republic, } \\
\text { Chad, Colombia, Congo, } \\
\text { Cote d'Ivoire, Democratic } \\
\text { Republic of the Congo, } \\
\text { Ecuador, Equatorial Guinea, } \\
\text { Ethiopia, French Guiana, } \\
\text { Gabon, Guinea, Guinea- } \\
\text { Bissau, Gambia, Ghana, } \\
\text { Guyana, Kenya, Liberia, } \\
\text { Mali, Mauritania, Niger, } \\
\text { Nigeria, Panama, Paraguay, } \\
\text { Peru, Rwanda, Senegal, } \\
\text { Sierra Leone, Sudan, South } \\
\text { Sudan, Suriname, Trinidad } \\
\text { and Tobago, Togo, Uganda } \\
\text { and Venezuela. }\end{array}$} \\
\hline $\begin{array}{l}\text { Measles/ } \\
\text { Mumps/ } \\
\text { Rubella }\end{array}$ & $\begin{array}{l}\text { With a recent resurgence in } \\
\text { cases of Measles and } \\
\text { Rubella cases in Saudi } \\
\text { Arabia, it is recommended } \\
\text { that any travelers to the } \\
\text { country, including those } \\
\text { traveling to Hajj are up-to- } \\
\text { date on their MMR } \\
\text { vaccines (CDC 2017). }\end{array}$ & & \\
\hline
\end{tabular}

\section{Zika Virus and Dengue Fever}

Zika virus infection was at its peak during Hajj season of 2016 presenting concerns of the possibility of transmission of the infection due to the virus at Hajj. No human infection from Zika virus was reported from countries in the WHO Eastern Mediterranean Region, yet there has been serologic evidence of the circulation of the Zika virus reported in at least two countries, Pakistan and Egypt (Ahmed et al. 2016). Circulation of the virus is expected since various countries in the WHO Eastern Mediterranean region, such as Saudi Arabia, have a heavy infestation of Aedes aegypti and Aedes albopictus, which are the vectors responsible for the transmission of Zika virus, dengue, and chikungunya (Ahmed et al. 2016).

During Hajj, women are fully clothed making mosquito bites unlikely in comparison to Hajj attire for men, which is less restrictive. Attire for men leaves the right shoulder, neck, and head exposed making mosquito bites a more likely occurrence. Zika has been documented as being carried in semen; therefore, leaving the potential to transmit the virus during post-Hajj sexual intercourse.

Additionally, due to the dry climate in Saudi Arabia, it is a common practice for families to store water in shady areas of their homes leaving a suitable environment for mosquitoes to breed. Therefore, vector control is critical. Every Hajj season, the environmental team of the Saudi Ministry of Health focuses strategies on curtailing vector-human interfaces including indoor residual spraying, insecticide-treated nets, and protected windows and doorways since Aedes aegyptei are known to bite during the day. The precautions are conducted in advance of Hajj and after Hajj, in addition to continued health education efforts run by the Ministry of Health providing best practices for personal mosquito bite prevention and prevention of the emergence of a potential Zika or Dengue outbreak in Hajj premises (Ahmed et al. 2016). 


\section{Other Considerations}

In addition to seeking preventative medical care and ensuring proper vaccination, pilgrims can take practical steps to stay safe and healthy during their journey. The steps include attention to food safety, sanitary conditions, accidents and injuries, and environmental hazards such as cold or heat exhaustion (Ministry of Health Saudi Arabia 2017).

\section{Food Safety}

Acute food poisoning and gastroenteritis are common during Hajj (Abd El Ghany et al. 2017). Risk factors for transmission of gastrointestinal (GI) diseases include contaminated food through unhygienic preparation, improper food storage, contaminated water sources, and improper food handling. Hajj occurs during the extreme heat of the summer season in the KSA, which increases the risk of dehydration for pilgrims (Shafi et al. 2016).

To mitigate these risks, officials in the KSA have implemented measures to ensure food safety. The Ministry of Health restricts pilgrims from bringing fresh food and agricultural products into the country (Shafi et al. 2016). Approved sealed or canned food and food stored in containers with easy access for inspection are allowed in small quantities that are sufficient for one person for the duration of the trip (Algarni et al. 2016). The pilgrim should make sure food is healthy and free from microbes, bacteria, or parasites.

Contaminated food and water often pose a risk for pilgrims therefore food should be selected with care. Undercooked or raw meat and fish (including shellfish) can carry various intestinal and systemic pathogens. Pilgrims should also avoid consuming salads, unpasteurized juices, and milk in areas where hygiene and sanitation are inadequate or unknown. Perishable cooked food should always be refrigerated and expiration date on canned items should also be checked.

Pilgrims should be aware not to consume exposed food, as the consumption of food and beverages obtained from street vendors has been associated with an increased risk of illness.

Proper food preparation and handling, washing fresh fruits and vegetables thoroughly, and cooking meat well reduces contamination. Adequate fluid intake of minerals from trusted sources replenishes electrolytes throughout the body (United State Department of State's Bureau of Consular Affair 2017).

The Saudi Food and Drug Authority also recommends that pilgrims be aware of street vendors as food is often prepared in unsanitary conditions causing the spread of microbes that cause foodborne illnesses. When a foodborne illness situation occurs, a pilgrim should look for symptoms of fever, nausea, vomiting, and diarrhea. In such cases, the pilgrim should be taken to the nearest hospital for medical attention, identify the food in question, and take the necessary precaution to prevent recurrence and further transmission (Saudi Food and Drug Authority 2018).

In summary, food safety tips include washing fruits and vegetables, washing hands before eating or preparing food, eating cooked food immediately, and avoiding food storage on buses or other means of transportation for extended periods 
of time. The aforementioned tips decrease the risk of food poisoning significantly (Ministry of Health Saudi Arabia 2017).

\section{General Hygiene and Cleanliness}

Pilgrims can take simple steps to reduce the risk of infections by maintaining personal hygiene and staying clean. Regular bathing and washing hands with soap and water can reduce the risk of becoming ill. All individuals can use a face mask in crowded places, properly dispose of waste in sanitary bins, and avoid spitting on the floor to reduce the spread of potential infectious agents (Ministry of Health Saudi Arabia 2017).

\section{Accidents and Injuries}

Accidents and injuries are common among pilgrims. A large number of Hajj pilgrims have to travel by foot walking long distances through dense traffic or motor vehicles. Road traffic accidents are also a potential hazard, which contribute to causalities and deaths during Hajj (Shujaa and Alhamid 2015; Dong et al. 2017; Alqahtani et al. 2017).

Minor injuries to the feet are relatively common, particularly among pilgrims with diabetes, while walking long distances. All foot injuries associated with other health conditions such as diabetes should be assessed carefully by healthcare professionals (Ministry of Health Saudi Arabia 2017).

Stampede is perhaps the most serious injury-causing event that occurs during Hajj. As pilgrims undertake the stoning rite or other mass activities, stampede can contribute to fatalities. In such large crowds, causalities can result from asphyxiation or head injuries in which emergency assistance is difficult to obtain quickly (Shujaa and Alhamid 2015). Significant improvements and modifications have been made by the Saudi Government to ensure the safety of pilgrims and reduce the risk of crowding such as the use of crowd simulation models, assessment of the efficient ways of grouping and scheduling pilgrims, luggage management, video monitoring, and changes in the transport system are the latest measures to improve the management of the pilgrimage event. (Klüpfel 2007; United States Department of State 2015).

\section{Environmental Hazards}

In summer, temperatures can rise higher than $45^{\circ} \mathrm{C}$, which can put pilgrims at risk for heat exhaustion, heat stroke, and dehydration (Shujaa and Alhamid 2015). With the lack of acclimatization, inadequate rest, and exposed spaces with limited or no shade, heat stroke can occur among many pilgrims. Hajj pilgrims should be advised to have adequate rest, maintain hydration with safe liquids, seek shade or use umbrellas, perform rituals at night, and wear high-sun protection factor (SPF) sunblock (Ministry of Health Saudi Arabia 2017).

The Saudi Ministry of Health has endeavored to provide shade in most of the crowded areas. Water mist sprays have been implemented for regular operation at the time of high risk for heat stroke as pilgrims may stand for periods of time during the day (Ministry of Health Saudi Arabia 2017). 


\section{Non-pharmaceutical Interventions}

The use of face masks and other such non-pharmaceutical methods to combat and mitigate the effects of exposure to pathogens and high-risk environments is a common alternate route to preventative measures taken by pilgrims and travelers. The face mask, an affordable and effective way to prevent and protect travelers and visitors from risks associated with transmittable and infectious airborne diseases (Wang et al. 2015).

\section{How to Stay Safe: Role of Health Authorities}

Travelers should consult with their medical provider at least 4-6 weeks in advance of departure to allow for adequate time to receive the recommended and required vaccinations for travel and discuss their medical history during their pre-travel consultation. Clinicians should reiterate the risks associated with the mass gatherings by identifying travel requirements and personal hygiene recommendations. For example, individuals performing Hajj are required to receive the quadrivalent meningococcal vaccine before traveling to the KSA, whereas other travelers to the KSA are not required to receive the vaccine (Center for Disease Control 2016; Yezli et al. 2016; Al-Tawfiq et al. 2018).

For many non-Muslim healthcare providers, the care of Muslim patients provides challenges. Cultural competency is an important aspect to aid healthcare professionals in delivering appropriate healthcare in culturally sensitive manner. Through understanding religious beliefs, health and illness as well as privacy concerns. All healthcare providers should be able to provide culturally competent care and can discuss travel itinerary, planned activities, and any travel recommendations provided by host sites to ensure the health and safety of pilgrims. For example, in response to the emergence in 2013 of MERS-CoV, health officials of Saudi Arabia recommended that the elderly or individuals with an immune-compromised system reschedule their pilgrimage. Clinicians should make pilgrims aware of preventive measures during their travel, such as practicing good hand hygiene and choosing safe food and water sources (United States Department of State 2015).

\section{Government Preparedness}

The KSA uses a well-coordinated, inter-sectoral approach to the planning, communications, public health, and safety issues of Hajj. Plans for Hajj begin immediately at the end of the current Hajj and the KSA Ministry of Hajj and Ministry of Health liaise along with government officials from the countries of pilgrims attending. Recommendations are discussed for pre-travel health regulations, advice on vaccinations, health checks, and specific immunizations required at the port of entry (Shafi et al. 2016).

Prior to the upcoming Hajj, the KSA Ministry of Health prepares public health communications on the health requirements for the issuance of travel visas. 
Health education campaigns are conducted through educational materials and resources to travel agents, pilgrim group leaders, websites, and the media before and during Hajj (Shafi et al. 2016; Alzahrani and Kyratsis 2017). The KSA Government also provides regular updates on Hajj travel guidance and health regulations through international public health agencies such as the WHO, Public Health England, the Centers for Disease Control and Prevention (CDC), and Hajj travel agencies.

During Hajj, an additional 25,000 health workers are deployed, and eight hospitals with state of-the-art equipment and intensive care units are made available specifically for pilgrims (Ministry of Health Saudi Arabia 2017). All medical facilities offer high-quality healthcare and services free to Hajj pilgrims to minimize adverse health risks.

\section{Relevant Procedures Pertaining to Travel}

Travelers must ensure all immunizations and health records are up-to-date and prepare an adequate supply of hand hygiene products and medications for any preexisting illnesses and prevention. Transportation is provided upon arrival, and travelers must expect longer wait times for public transit. Pilgrims must also follow the guidance on bringing religious articles back to their country of origin for their own safety and health (United State Department of State's Bureau of Consular Affair 2017).

\section{Health Education}

Governments and health authorities are required to provide information to traveling pilgrims on infectious diseases and noncommunicable diseases, modes of transmission, methods of prevention, and public health implications (Algarni et al. 2016; Alqahtani et al. 2016a). For example, an article announced the Ministry of Health and Prevention launched an awareness campaign focusing on health and safety for Hajj pilgrims (MENA Herald 2016). The aim was to ensure the safety and health of Hajj pilgrim in cooperation with the Health Authority-Abu Dhabi (HAAD) and the Dubai Health Authority (DHA). The campaign focused on the well-being of pilgrims; especially the elderly and individuals suffering from chronic illnesses regardless of age. The campaign included medical advice on heat exhaustion, awareness about healthy foods, personal care, emergency medicine, and available vaccines (MENA Herald 2016).

The KSA Ministry of Health represented by the Awareness and Health Promotion General Department, in collaboration with the Sanofi Company, launched a similar health campaign entitled "Together for a Healthy Pilgrimage." The objective of the campaign was to promote awareness among pilgrims about the health requirements during the 2016 Hajj season with a key focus on vaccinations and health misconceptions among pilgrims performing Hajj rituals (Ministry of Health Saudi Arabia 2017). The campaign was printed in 10 languages with numerous numbers of 
publications for distribution to pilgrims inside and outside the KSA. Also, the campaign produced four awareness films including health tips and guidelines on heat exhaustion, sunstrokes, food poisoning, and infection control as well as an awareness application about pilgrimage (Ministry of Health Saudi Arabia 2017).

\section{Conclusion}

Decision-makers, government officials, health service providers, and attendees all play a role in the success, health, and safety of a mass gathering. For a mass gathering to be successful in promoting and maintaining public health throughout the event, a public health surveillance system; strong regulations, legislation, and policies; and thorough emergency planning and response arrangements are needed. Attention to the environment; strong communication systems taking advantage of technology as well as ongoing capacity building are essential for public health preparedness. The implementation of a framework that has a strong foundation including these key aspects should be the top priority for individuals organizing mass gatherings, including Hajj/Umrah.

The primary gap in knowledge according to the research is in the behavioral effects of mass gatherings, rather than the dangers of having a large population gathering in one area. The literature which does not take into account mass behavior patterns associated with ritual, with religious pilgrimage, and with traditions tends to prioritize a reading that emphasizes the gathering's size over its behavioral aspect. Pilgrims attending Hajj must make themselves aware of the necessary precautions and discuss these issues with their healthcare provider. Such precautions include maintaining routine hygiene including hand washing, taking care in food preparation, and accessing safe water sources. Such basic advice may seem commonplace for any type of travel; however, the nature of attendance at such a mass gathering such as Hajj can make basic travel precautions more difficult to maintain. In knowing this, the KSA officials make every attempt to provide detailed public health information to pilgrims attending Hajj, including familiarizing them with the compliance that is expected before pilgrims begin their journey.

Pilgrims attending Hajj can take steps themselves to ensure they return home safe and healthy. Receiving proper vaccinations, talking with a medical provider, and bringing appropriate supplies before traveling will allow for a safer and healthier experience. The ability to access information, taking steps to ensure health hygiene habits, and being aware of exit avenues and emergency procedures and services during the gathering will help ensure health and safety for all. Knowledge from past situations and teaching future pilgrims can build upon the experiences of pilgrims and translate that information to future attendees. 


\section{References}

Abd El Ghany M, Sharaf H, Hill-Cawthorne GA (2016) Hajj vaccinations - facts, challenges, and hope. Int J Infect Dis 47:29-37

Abd El Ghany M, Alsomali M, Almasri M, Padron Regalado E, Naeem R, Tukestani A, Asiri A, Hill-Cawthorne G, Pain A, Memish Z (2017) Enteric infections circulating during Hajj seasons, 2011-2013. Emerg Infect Dis 23(10). https://doi.org/10.3201/eid2310.161642

Ahmed QA, Kattan RF, Memish ZA (2016) Hajj 2016: under the shadow of global Zika spread. Am J Infect Control 44(12):1449-1450. https://doi.org/10.1016/j.ajic.2016.09.002

Alaska Y, Aldawas A, Aljerian N, Memish Z, Suner S (2016) The impact of crowd control measures on the occurrence of stampedes during mass gatherings: the Hajj experience. Travel Med Infect Dis 15:67-70. https://doi.org/10.1016/j.tmaid.2016.09.002

Aleeban M, Mackey TK (2016) Global Health and visa policy reform to address dangers of Hajj during summer seasons. Front Public Health 4:280. https://doi.org/10.3389/fpubh.2016.00280

Algarni H, Memish ZA, Assiri AM (2016) Health conditions for travellers to Saudi Arabia for the pilgrimage to Mecca (Hajj) - 2015. J Epidemiold Glob Health 6(1):7-9. https://doi.org/10.1016/ j.jegh.2015.07.001

Alharbi N, Al-Barrak A, Al-Moamary M, Zeitouni M, Idrees M, Al-Ghobain M, Al-Shimemeri A, Al-Hajjaj M (2016) The Saudi thoracic society pneumococcal vaccination guidelines - 2016. Ann Thorac Med 11(2):93-102

Alqahtani A, Sheikh M, Wiley K, Heywood A (2015) Australian Hajj pilgrims' infection control beliefs and practices: insight with implications for public health approaches. Travel Med Infect Dis. https://doi.org/10.1016/j.tmaid.2015.05.009

Alqahtani AS, Wiley KE, Mushta SM, Yamazaki K, BinDhim NF, Heywood AE, Booy R, Rashid H (2016a) Association between Australian Hajj Pilgrims' awareness of MERS-CoV, and their compliance with preventive measures and exposure to camels. J Travel Med 18:23(5). https:// doi.org/10.1093/jtm/taw046

Alqahtani A, Wiley K, Tashani M, Willaby H, Heywood A, BinDhim N, Booy R, Rashid H (2016b) Exploring barriers to and facilitators of preventive measures against infectious diseases among Australian Hajj pilgrims: cross-sectional studies before and after Hajj. Int Soc Infect Dis 47:53-59. https://doi.org/10.1016/j.ijid.2016.02.005. Epub 10 Feb 2016

Alqahtani A, Yamazaki K, Alqahtani W, Tashani M, Heywood A, Booy R, Wiley K, Rashid H (2017) Australian Hajj pilgrims' perception about mass casualty incidents versus emerging infections at Hajj. Travel Med Infect Dis 15:81-83. https://doi.org/10.1016/j.tmaid.2016.11.002

Al-Tawfiq JA, Gautret P, Benkouiten S, Memish ZA (2016) Mass gatherings and the spread of respiratory infections. Lessons from the Hajj. Ann Am Thorac Soc 13:759-765

Al-Tawfiq JA, Gautret P, Memish ZA (2017) Expected immunizations and health protection for Hajj and Umrah 2018 - an overview. Travel Med Infect Dis. https://doi.org/10.1016/j. tmaid.2017.10.005

Alzahrani F, Kyratsis Y (2017) Emergency nurse disaster preparedness during mass gatherings: a cross-sectional survey of emergency nurses' perceptions in hospitals in Mecca, Saudi Arabia. Br Med J 7(4):e013563. https://doi.org/10.1136/bmjopen-016-013563

Arbon P (2004) The development of conceptual models for mass-gathering health. Prehosp Disaster Med 19:208-212

Armstrong K (2002) Islam: a short history. Modern Library, New York. Retrieved from http://www. islamlaws.com/wp-content/uploads/2014/10/Islam-A-Short-History-Karen-Armstrong.pdf on 20 Jan 2018

Bowron C, Salahudin M (2015) Saudi Arabia: Hajj Pilgrimage. Retrieved from https://wwwnc.cdc. gov/travel/yellowbook/2016/select-destinations/saudi-arabia-hajj-pilgrimage on 20 Jan 2018

Center for Disease Control (2015) Meningococcal Disease (Neisseria meningitidis). Retrieved from https://wwwnc.cdc.gov/travel/diseases/meningococcal-disease on 13 Dec 2016 
Centers for Disease Control and Prevention (2017) Health information for travelers to Saudi Arabia. Retrieved from https://wwwnc.cdc.gov/travel/destinations/traveler/none/saudi-arabia on 20 Jan 2018

Cobbin JCA, Alfelali M, Barasheed O, Taylor J, Dwyer DE, Kok J, Booy R, Holmes EC, Rashid H (2017) Multiple Sources of genetic diversity of influenza A viruses during the Hajj. J Virol 91(11). pii: e00096-17. https://doi.org/10.1128/JVI.00096-17

Coghlan A (2015, September 9) MERS warning as pilgrims prepare to visit Mecca during outbreak. Retrieved from https:/www.newscientist.com/article/dn28147-mers-warning-as-pilgrims-pre pare-tovisit-mecca-during-outbreak/ on 20 Jan 2018

Dong YH, Liu F, Liu YM, Jiang XR, Zhao ZX (2017) Emergency preparedness for mass gatherings: lessons of "12.31" stampede in Shanghai Bund. J Trauma 4:240-242. https://doi.org/ 10.1016/j.cjtee.2016.08.005

Finger F, Genolet T, Mari L, de Magny GC, Manga NM, Rinaldo A, Bertuzzo E (2016) Mobile phone data highlights the role of mass gatherings in the spreading of cholera outbreaks. Proc Natl Acad Sci USA 113(23):6421-6426. https://doi.org/10.1073/pnas.1522305113

Gautret P, et al. (2016) Hajj-associated viral respiratory infections: A systematic review. Travel Med Infect Dis.

Kazi DS, Greenough PG, Madhok R, Heerboth A, Shaikh A, Leaning J, Balsari S (2017) Using mobile technology to optimize disease surveillance and healthcare delivery at mass gatherings: a case study from India's Kumbh Mela. J Public Health 39(3):616-624. https:// doi.org/10.1093/pubmed/fdw091

Khan I, Khan S, Asima B, Hussaini S, Zakiuddin M, Faisal F (2017) Morbidity and mortality amongst Indian Hajj pilgrims: a 3-year experience of Indian Hajj medical mission in massgathering. J Infect Public Health 11(2):165-170. https://doi.org/10.1016/j.jiph.2017.06.004

Klüpfel H (2007) The simulation of crowd dynamics at very large events - calibration, empirical data, and validation. In: Pedestrian and evacuation dynamics 2005. Springer, New York, pp 285-296

Leangapichart T, Rolain JM, Memish ZA, Al-Tawfiq JA, Gautret P (2017) Emergence of drug resistant bacteria at the Hajj: a systematic review. Travel Med Infect Dis 18:3-17. https://doi. org/10.1016/j.tmaid.2017.06.008

Lingappa J, Al-Rabeah A, Hajjeh R, Mustafa T, Fatani A, Al-Bassam T, Badukhan A, Turkistani A, Al-Hamdan N, Al-Jeffri M, Al Mazrou Y, Perkins BA, Popovic T, Mayer L, Rosenstein N (2003) Serogroup W-135 meningococcal disease during the Hajj, 2000. Emerg Infect Dis 9(6):665-671

MENA Herald, Dubai (2016) Ministry of Health \& Prevention launches awareness campaign focusing on health \& safety for Hajj pilgrims. Retrieved from https://www.menaherald.com/ en/business/healthcare/ministry-health-prevention-launches-awareness-campaign-focusinghealth-safety on 20 Jan 2018

Ministry of Health Saudi Arabia (2017) Health Guidelines Requirements for Travelers to Saudi Arabia for Pilgrimage to Makkah]. Retrieved from https://www.moh.gov.sa/en/Hajj/ HealthGuidelines/Pages/default.aspx on 20 Jan 2018

Rafiq SM, Rashid H, Haworth E, Booy R (2009) Hazards of hepatitis at the Hajj. Travel Med Infect Dis 7:239-246

Rahimian M, Hosseini B (2017) Serological study of Bordetella pertussis, mycoplasma pneumonia and chlamydia pneumonia in Iranian Hajj pilgrims with prolonged cough illnesses: a follow-up study. Respir Med 132:122-131. https://doi.org/10.1016/j.rmed.2017.10.009. Epub 13 Oct 2017

Rahman J, Thu M, Arshad N, Van der Putten M (2016) Mass gatherings and public health: case studies from the Hajj to Mecca. Ann Glob Health 83(2):386-393. https://doi.org/ 10.1016/j.aogh.2016.12.001

Saudi Food and Drug Authority (2018). Retrieved from http://www.sfda.gov.sa/ar/Pages/default. aspx on 28 Dec 2016

Shafi S, Dar O, Khan M, Khan M, Azhar EI, McCloskey B, Petersen E (2016) The annual Hajj pilgrimage - minimizing the risk of ill health in pilgrims from Europe and opportunity 
for driving the best prevention and health promotion guidelines. Int J Infect Dis 47:79-82. https://doi.org/10.1016/j.ijid.2016.06.013

Shirah BH, Zafar SH, Alferaidi OA, Sabir AMM (2017) Mass gathering medicine (Hajj pilgrimage in Saudi Arabia): the clinical pattern of pneumonia among pilgrims during Hajj. J Infect Public Health 10(3):277-286. https://doi.org/10.1016/j.jiph.2016.04.016

Shujaa A, Alhamid S (2015) Health response to Hajj mass gathering from emergency and respective, narrative review. Turk J Emerg Med 15(4):172-176. https://doi.org/10.1016/j. tjem.2015.02.001. Published online 9 Mar 2016. PMCID: PMC4882208

Tsouros A, Efstathiou P (2007) Mass gatherings and public health: the experience of the Athens 2004 Olympic Games, World Health Organisation Europe, EU/07/5062470. Retrieved from http://www.euro.who.int/datapublications/Publications/Catalogue/20071001_1 on 20 Jan 2018

United States Department of State (2015) CDC: Hajj and Umrah in Saudi Arabia. Retrieved from https://www.osac.gov/pages/ResourceLibraryDetails.aspx?cid=17609 on 20 Jan 2018

United States Department of State's Bureau of Consular Affairs (2017) Before you go Hajj and Umrah Fact Sheet. Retrieved from https://travel.state.gov/content/travel/en.html on 20 Jan 2018

Wang M, Barasheed O, Rashid H, Booy R, El Bashir H, Haworth E, Ridda I, Holmes EC, Dwyer DE, Nguyen-Van-Tam J, Memish ZA, Heron L (2015) A cluster-randomised controlled trial to test the efficacy of facemasks in preventing respiratory viral infection among Hajj pilgrims. J Epidemiol Glob Health 5(2):181-189. https://doi.org/10.1016/j.jegh.2014.08.002

World Health Organization (2005) Mass gatherings. Retrieved from http://www.who.int/ihr/ith and_mass_gatherings/mass_gatherings/en/ on 20 Jan 2018

World Health Organization (2015) Public health for mass gatherings: key considerations. Retrieved from http://www.who.int/ihr/publications/WHO_HSE_GCR_2015. 5/en/ on 20 Jan 2018

World Health Organization (2016a) Draft global health strategy on viral hepatitis, 2016-2021. Retrieved from https:/www.who.int/hepatitis/strategy20162021/Draft_global_health_sector_ strategy_viral_hepatitis_1nov.pdf on 20 Jan 2018

World Health Organization (2016b) Temporary Yellow Fever vaccination requirements for International Travelers related to current outbreaks in Africa. Retrieved from http://www.who. int/ith/updates/20160725/en/ on 20 Jan 2018

Yezli S, Assiri AM, Alhakeem RF, Turkistani AM, Alotaibi B (2016) Meningococcal disease during the Hajj and Umrah mass gatherings. Int J Infect Dis 47:60-64. https://doi.org/10.1016/j. ijid.2016.04.007

Yezli S, Zumla A, Yassin Y, Al-Shangiti AM, Mohamed G, Turkistani AM, Alotaibi B (2017) Undiagnosed active pulmonary tuberculosis among pilgrims during the 2015 Hajj mass gathering: a prospective cross-sectional study. Am J Trop Med Hyg 97(5):1304-1309. https:// doi.org/10.4269/ajtmh.17-0271. Epub10 Oct 2017

Zaki AM, van Boheemen S, Bestebroer TM, Osterhaus AD, Fouchier RA (2012) Isolation of a novel coronavirus from a man with pneumonia in Saudi Arabia. N Engl J Med 367:1814-1820. https://doi.org/10.1056/NEJMoa1211721

Zumla A, Alagaili AN, Cotten M, Azhar EI (2016) Infectious diseases epidemic threats and mass gatherings: refocusing global attention on the continuing spread of the Middle East Respiratory syndrome coronavirus (MERS-CoV). BMC Med 14(1):132. https://doi.org/10.1186/s12916016-0686-3 